\title{
Mercury contamination of bottom sediments in water reservoirs of southern Poland
}

\author{
Tomasz Koniarz¹, Marek Tarnawski¹, Agnieszka Baran², Natalia Florencka ${ }^{3}$ \\ ${ }^{1}$ University of Agriculture in Krakow, Department of Water Engineering and Geotechnics; \\ al. Mickiewicza 24/28, 30-059 Krakow, Poland; e-mail: rmtarnaw@cyf-kr.edu.pl \\ ${ }^{2}$ University of Agriculture in Krakow, Department of Agricultural and Environmental Chemistry; \\ al. Mickiewicza 21,31-120 Krakow, Poland; e-mail: Agnieszka.Baran@ur.krakow.pl \\ ${ }^{3}$ AGH University of Science and Technology, Faculty of Mining Surveying and Environmental Engineering, \\ al. Mickiewicza 30,30-059 Krakow, Poland; e-mail: floren@agh.edu.pl
}

\begin{abstract}
(c) 2015 Authors. This is an open access publication, which can be used, distributed and reproduced in any medium according to the Creative Commons CC-BY 4.0 License requiring that the original work has been properly cited.
\end{abstract}

Received: December 2014; accepted: April 2015

\begin{abstract}
The aim of this study was to assess the mercury concentration in bottom sediments, collected from eight reservoirs located in south-eastern Poland. A DMA-80 Mercury Analyser was used for the analysis of the concentration of mercury in bottom sediments. Concentration of mercury in sediments was between 0.01-0.18 mg. $\mathrm{kg}^{-1}$. The research results show that 13 samples are above the Polish $\mathrm{Hg}$ background level. Only 9 samples are below the background level. Generally, the sediments belonged to class I and II (unpolluted and moderately polluted sediments). The concentration of mercury in bottom sediments follows the order: Rybnik (highest) > Bagna Rzeszowskie > Rzeszów > Ożanna > Brzóza Stadnicka > Brzóza Królewska > Głuchów > Narożniki (lowest). The low mercury content in sediments is related to absent or limited anthropogenic sources of this metal. Elevated concentrations of $\mathrm{Hg}$ in bottom sediments of the reservoirs in Rybnik and Bagna Rzeszowskie are related to their proximity to large agglomerations and industrial plants. Organic matter was likely to be the most important factors controlling the concentration and distribution of mercury in the studied sediments.
\end{abstract}

Keywords: mercury, bottom sediments, reservoirs, geoaccumulation parameters

\section{INTRODUCTION}

Sediments accumulating at the bottom of watercourses and reservoirs have various compositions which depend on the composition of source rocks in river basins, the geomorphology of the area, climatic conditions and, also, on the management, of the use of the river basin area and pollutants reaching the waters (Bojakowska et al. 2006). Bottom sediments are living and feeding grounds for many organisms. Polluted sediments result in poisoning and diseases of aquatic species, thus affecting people and animals at higher food-chain levels (Tarnawski et al. 2013). The mercury occurring in the environment is in two different forms: volatile
$\left(\mathrm{Hg},\left(\mathrm{CH}_{3}\right)_{2} \mathrm{Hg}\right)$, easily water soluble $\left(\mathrm{Hg}^{2+}, \mathrm{HgCl}_{2}\right.$, $\left.\mathrm{Hg}\left(\mathrm{NO}_{3}\right)_{2}\right)$ and hardly soluble organic complexes $\left(\mathrm{CH}_{3} \mathrm{Hg}^{+}, \mathrm{CH}_{3} \mathrm{HgS}\right)$ (Boszke et al. 2002). Depending on environmental conditions, mercury bound in bottom sediments can easily be remobilized. Distribution of mercury compounds depends mainly on redox conditions (Kabata-Pendias \& Pendias 1999). Moreover, both biotic and abiotic processes, responsible for the reduction and methylation of mercury, can affect its mobilization (Capri \& Lindberg 1997). The quality of sediments is an essential indicator of water pollution with this element. The content of mercury in bottom sediments is highly variable (Hintelman \& Wilken 1995). Natural mercury content in sediments of Polish 
reservoirs does not exceed $0.05 \mathrm{mg} \cdot \mathrm{kg}^{-1}$ d.m. (Kabata-Pendias \& Pendias 1999). In studies undertaken by Lis \& Pasieczna (1995) found that the content of mercury in bottom sediment ranged from $<0.05$ to $11.0 \mathrm{mg} \cdot \mathrm{kg}^{-1} \mathrm{~d}$.m. For example, the bottom sediments of the Elbe River (Germany) were highly polluted with mercury, where the total content reached $12 \mathrm{mg} \cdot \mathrm{kg}^{-1} \mathrm{~d}$.m. Moreover, the mercury concentrations reported for the extremely polluted Minamata Bay (Japan) were up to $0.91 \mathrm{mg} \cdot \mathrm{kg}^{-1} \mathrm{~d} . \mathrm{m}$. (Boszke et al. 2003). Higher concentrations of mercury in the coastal zones and river estuaries are a result of the transportation of this element with river waters polluted, with mercury bound to the suspension phase (Boszke et al. 2003).

The aim of this study was to assess mercury concentrations in bottom sediments collected from eight reservoirs located in south-eastern Poland. Moreover, a relationship between the concentration of mercury and the physicochemical parameters of sediments was studied.

\section{GEOGRAPHIC SETTING}

Samples of bottom sediments were taken from eight reservoirs located in south-eastern Poland (Fig. 1). The Rybnik Reservoir is the largest of the examined objects and the only one located in Silesia. It was built in 1972 at the confluence of the Ruda and Nacyna rivers, in order to provide process water for the Rybnik Power Plant. The reservoir is also used for flood protection and recreation. The total area of the reservoir is 555 ha and its capacity is 24 million $\mathrm{m}^{3}$. The waters of Nacyna, under normal conditions, due to their heavy contamination, are pumped below the Rybnik Reservoir. The remaining examined reservoirs are located in the Subcarpathian Voivodeship. The Rzeszów reservoir on the Wisłok River with the capacity of 1.8 million $\mathrm{m}^{3}$ and the area of 68.2 ha, was built in 1973. Its main task is to enable water intake for the Rzeszów city water supply system, to protect from floods and to provide sport and leisure activities.

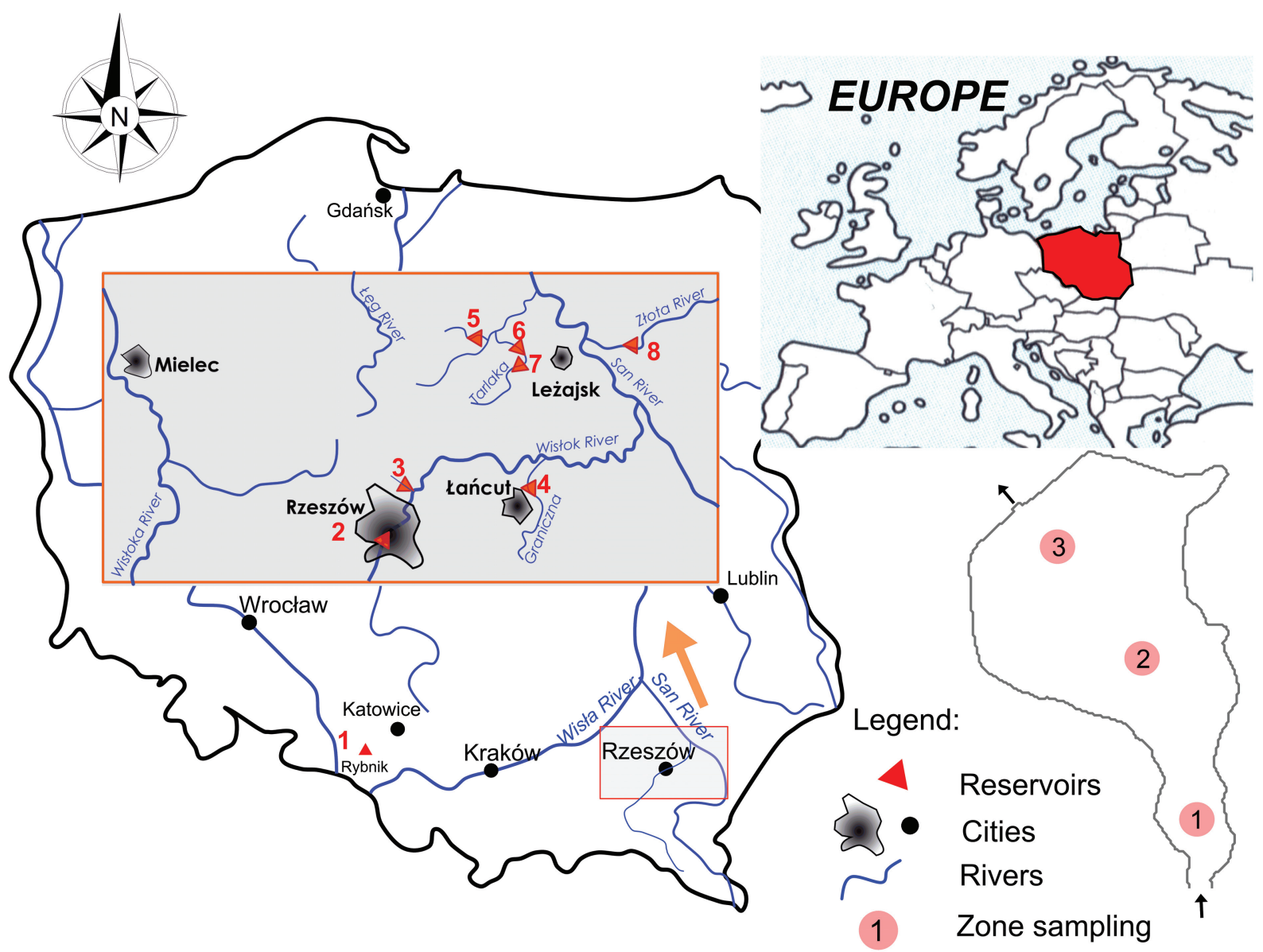

Fig. 1. Location of reservoirs: 1 - Rybnik, 2 - Rzeszów, 3 - Bagna Rzeszowskie, 4 -Głuchów, 5 - Narożniki, 6 - Brzóza Królewska, 7 - Brzóza Stadnicka, 8 - Ożanna 
Measurements conducted after 14 years of the reservoir operation revealed its diminished capacity by c.a. $66 \%$ and loss of the impoundment area by 18.5 ha, constituting permanently or periodically overgrown islands and shallows. The reservoir was unsuccessfully deepened and modernized in the eighties and nineties. The Bagna Rzeszowskie Reservoir on the Czarna River is a small reservoir; located north of Rzeszów. This reservoir, which was built in the 1970s, with the capacity of c.a. 48 thousand $\mathrm{m}^{3}$ and the area of about 1.5 ha, has not been subject to renovation so far. The Głuchów Reservoir near the town of Łańcut, with the capacity of 22.6 thousand $\mathrm{m}^{3}$ and the area of $1.50 \mathrm{ha}$, was built on the Graniczny Stream. This reservoir was established in 1995 and was intended to be a place for rest and recreation. The reservoir in Narożniki is situated on the Dęba Stream and was put into operation in 2001. The capacity of this reservoir is 283.8 thousand $\mathrm{m}^{3}$ and the area is $24 \mathrm{ha}$. The main purposes of the reservoir comprise water retention, balancing of flows to regulate water relationships, reduction of flood waves and recreational facilities. At the turn of 2011-2012, the reservoir was partially dredged. The reservoir in Brzóza Królewska is located in the valley of the Tarlak River. The reservoir was established in 1978, with the purpose of providing recreational facilities. The reservoir has the capacity of 48.8 thousand $\mathrm{m}^{3}$ and an area of $6.13 \mathrm{ha}$. At the same river (Tarlak), $4 \mathrm{~km}$ upstream, there is the Brzóza Stadnicka Reservoir. This reservoir is located in the area of swampy agricultural wasteland. It was put into operation in 1995 and has the capacity of only 7 thousand $\mathrm{m}^{3}$ and the area of 1.15 ha.

\section{MATERIALS AND METHODS}

\section{Sampling of bottom sediment}

The samples were collected using an Ekman sampler from three set locations: inlet (backwater), middle and outlet (near the dam) zones. 5-6 samples were taken from each zone and mixed in order to average the properties of sediments in samples representative of a given zone. The sediments were collected from the $0-15 \mathrm{~cm}$ layer. All sediment samples ( 24 samples, $20-25 \mathrm{~cm}^{3}$ material per sample) were refrigerated until analyzed.

\section{PHYSICAL AND CHEMICAL ANALYSIS}

After drying, size distribution of the samples was determined in accordance with standard EN ISO 14688-1:2002 E. The sediment samples were analyzed for: $\mathrm{pH}$ and organic matter concentration. The $\mathrm{pH}$ value was measured at a 1:2.5 sediment: liquid ratio with $1 \mathrm{~mol} \mathrm{KCl} \cdot \mathrm{dm}^{-3}$ by potentiometric method. The analysis also involved measuring the liquid ratio with $1 \mathrm{~mol} \mathrm{KCl} \cdot \mathrm{dm}^{-3}$ by the potentiometric method. Organic matter concentration was determined by the loss-on-ignition for $8 \mathrm{~h}$ at $550^{\circ} \mathrm{C}$ (Baran \& Tarnawski 2013). After drying and crushing of the material, the total concentration of mercury in the sediment samples was determined. A DMA-80 Mercury Analyser was used for the analysis. The DMA-80 combines the techniques of thermal decomposition, catalytic conversion, amalgamation, and atomic absorption spectrophotometry. In first place, the sample was dry and thermally decomposed and introduced into a quartz tube. All mercuric compounds were reduced to their elemental $\mathrm{Hg}$ and then carried along to a gold amalgamator, where the mercury was selectively trapped. The system was purged and the amalgamator was subsequently heated, which released all mercury vapours to a single beam and to a fixed wavelength atomic absorption spectrophotometer. Here, the absorbance measured at $253.7 \mathrm{~nm}$ was proportional to the mercury content in the sample (http://www. milestonesci.com). The results were verified statistically using the Statistica 10 software package. Accuracy of the analyses was tested using reference material CRM16-050. Sediment samples were analyzed in three replicates for which the relative standard deviations (\%RSDs) were less than 10\% for all metals. The analytical results of the quality control samples were in good agreement with the certified values, recoveries ranging from $95-100 \%$.

\section{Geochemical analysis}

Geochemical parameters were used in the assessment of the pollution of sediments with mercury. The following indicators were used in the paper: guidelines of the Polish National Geological Institute (PIG) (Bojakowska \& Sokołowska 1998), geoaccumulation index $\left(I_{\text {geo }}\right)$ (Müller 1981) and 
contamination factor $\left(C_{f}\right)$ (Håkanson 1980). Geochemical background (equal $0.05 \mathrm{mg} \cdot \mathrm{kg}^{-1}$ ) was adopted for calculations for bottom sediments (Lis \& Pasieczna 1995).

\section{RESULTS AND DISCUSSION}

The main physico-chemical properties of the bottom sediments are presented in Table 1 . The sediments showed an acid reaction (Brzóza Stadnicka, Ożanna), slight acid (Rybnik, Bagna Rzeszowskie, Brzóza Królewska), neutral (Rzeszów, Narozniki), and alkaline (Głuchów). The concentration of organic matter in the bottom sediments was between $4.8 \mathrm{~g} \cdot \mathrm{kg}^{-1} \mathrm{~d}$.m. (Narożniki) to $247.3 \mathrm{~g} \cdot \mathrm{kg}^{-1} \mathrm{~d}$.m. (Rybnik). Sediments showed a high diversity of grain size fraction distribution (Tab. 1). Based on grain size fraction, bottom material from the Rybnik reservoir contains form $34 \%$ to $54 \%$ of sand, from $22 \%$ to $43 \%$ of silt and from $23 \%$ to $25 \%$ of clay. The clay fraction (48-57\%) dominated in the bottom sediments, collected form the Rzeszów reservoir. Generally, in the bottom sediments, collected from the Bagna Rzeszowskie and Głuchów reservoirs, silt fraction dominated. According to the location of the reservoirs, Narożniki, Brzóza Królewska and Brzóza Stadnicka and Ożanna, the grain size characteristics of bottom sediments were similar.

The dominant grain size fraction in these sedimentations was sand.

Table 2 presents concentration of mercury in sediments. The examined sediments varied significantly both within the individual sections of a given reservoir and between the reservoirs. The concentrations of mercury in the examined sediment were highly diversified. The concentration distribution of the mercury in sediments increased with decreasing distance from the dam. The mercury concentrations in sediments by the dams of the Bagna Rzeszowskie, Głuchów, Narożniki, Brzóza Królewska and Brzóza Stadnicka reservoirs were up to 9 times higher that the concentrations of this metal in the sediments collected at reservoir inlets. In the bottom sediments form Rybnik, Ożanna and Rzeszów reservoirs, the maximum concentrations of mercury were found in the sediments collected from the middle of the reservoirs. The sediments of the reservoirs at Brzóza Królewska and Brzóza Stadnicka were characterized by very similar average concentration of mercury, amounting to 0.041 and $0.048 \mathrm{mg} \cdot \mathrm{kg}^{-1}$, respectively. This situation was probably caused by the fact that these reservoirs are located in the same river basin. Brzóza Stadnicka, enclosed in the basin of Brzóza Królewska, acts as an initial reservoir, capturing a portion of pollutants flowing in the Tarlak River. The highest mercury concentration was recorded in the bottom sediments of the reservoirs: Rybnik (0.181 $\left.\mathrm{mg} \cdot \mathrm{kg}^{-1}\right)$ and Bagna Rzeszowskie $\left(0.158 \mathrm{mg} \cdot \mathrm{kg}^{-1}\right)$. The probable reason for such high levels of this metal is the proximity of the reservoirs to urbanized areas. The obtained results do not differ from other authors' research, which showed that the mercury concentration in bottom sediments of retention reservoirs in Poland is on average between $0.07-0.18 \mathrm{mg} \cdot \mathrm{kg}^{-1}$ (Bojakowska et al. 2006).

\section{Table 1}

Main physicochemical parameters of the sediment

\begin{tabular}{|l|c|c|c|c|c|}
\hline \multirow{2}{*}{ Bottom sediments } & \multicolumn{3}{c|}{ Grain size fraction [\%] } & \multirow{2}{*}{ pH } & \begin{tabular}{c} 
Organic matter \\
[g.kg-1 \\
\cline { 2 - 5 } $\mathbf{d . m}]$.
\end{tabular} \\
\cline { 2 - 5 } Rybnik & sand & silt & clay & & 247.3 \\
\hline Rzeszów & $34-54$ & $22-43$ & $23-25$ & 6.3 & 23.5 \\
\hline Bagna Rzeszowskie & $7-9$ & $35-45$ & $48-57$ & 7.1 & 38.8 \\
\hline Głuchów & $22-27$ & $34-56$ & $20-30$ & 6.5 & 13.1 \\
\hline Narożnik & $17-20$ & $43-52$ & $28-41$ & 7.3 & 4.8 \\
\hline Brzóza Królewska & $26-86$ & $1-46$ & $5-28$ & 7.0 & 24.8 \\
\hline Brzóza Stadnicka & $43-90$ & $6-24$ & $4-33$ & 5.6 & 27.7 \\
\hline Ożanna & $49-90$ & $5-27$ & $5-24$ & 5.3 & 31.3 \\
\hline
\end{tabular}


Table 2

Concentration of mercury in bottom sediments $\left[\mathrm{mg} \cdot \mathrm{kg}^{-1} \mathrm{~d} . \mathrm{m}.\right]$

\begin{tabular}{|c|c|c|c|c|c|}
\hline \multirow{2}{*}{ Bottom sediements } & \multicolumn{3}{|c|}{ Area sampling* } & \multirow{2}{*}{ Mean } & \multirow{2}{*}{ SD } \\
\hline & 1 & 2 & 3 & & \\
\hline Rybnik & 0.168 & 0.181 & 0.162 & 0.170 & 0.009 \\
\hline Rzeszów & 0.082 & 0.085 & 0.083 & 0.084 & 0.002 \\
\hline Bagna Rzeszowskie & 0.156 & 0.158 & 0.160 & 0.158 & 0.002 \\
\hline Głuchów & 0.014 & 0.019 & 0.056 & 0.030 & 0.023 \\
\hline Narożnik & 0.011 & 0.022 & 0.025 & 0.020 & 0.007 \\
\hline Brzóza Królewska & 0.010 & 0.019 & 0.094 & 0.041 & 0.046 \\
\hline Brzóza Stadnicka & 0.025 & 0.051 & 0.069 & 0.048 & 0.022 \\
\hline Ożanna & 0.036 & 0.083 & 0.075 & 0.065 & 0.026 \\
\hline
\end{tabular}

${ }^{*} 1$ - inlet, 2 - middle, 3 - by the dam.

Many research studies have shown that the concentration of organic matter is the measurement of the capacity of bottom sediments to accumulate metals (Baran et al. 2011, Baran \& Tarnawski 2013). A positive significant correlation between the concentration of organic matter and the mercury concentration $(r=0.80, p<0.05)$ confirms the considerable share of organic matter in the binding of mercury. The positive relationships of mercury with the organic matter concentration of the sediment might be attributed to anthropogenic impacts (Farkas et al. 2007). Other important factors affecting metal concentration in sediment include the content of clay fraction (Farkas et al. 2007). The concentration of $\mathrm{Hg}$ was insignificantly correlated with sand (negatively, $r=-0.40$ ) silt and clay (positively, $r=0.45, r=0.30, p<0.05$ ). To sum up, the correlation analysis found that organic matter, sand and silt affected the concentration and the spatial distribution of mercury in sediments.

The geochemical indicators were shown in Table 3. According to Müller (1969), the $I_{\text {geo }}$ for each metal is calculated and classified as: uncontaminated $\left(I_{\text {geo }} \leq 0\right)$ - class 0 ; uncontaminated to moderately contaminated $\left(0<I_{\text {geo }} \leq 1\right)-$ class 1 ; moderately contaminated $\left(1<I_{\text {geo }} \leq 2\right)$ - class 2 ; moderately to heavily contaminated $\left(1<I_{\mathrm{geo}} \leq 2\right)-$ class 3 ; heavily contaminated $\left(3<I_{\text {geo }} \leq 4\right)-$ class 4; heavily to extremely contaminated $\left(4<I_{\text {geo }} \leq 5\right)$ - class 5 ; extremely contaminated $\left(5<I_{\text {geo }} \leq 6\right)-$ class 6 . The calculated indices of mercury geoaccumulation in bottom sediments of the examined reservoirs made it possible to categorize the reservoirs between class 0 (practically uncontaminated) and class 1 (slightly to moderately contaminated). The highest values of geoaccumulation index were found in the bottom sediments of the reservoirs: Rybnik, Rzeszów and Bagna Rzeszowskie, which put these sediments into category of class 1 . The results of the calculated contamination factor were more diversified, as compared to the geoaccumulation index. The highest values of the mercury contamination factor were observed for the sediments collected from the reservoirs Rybnik and Bagna Rzeszowskie.

Table 3

Geochemical indicators

\begin{tabular}{|l|c|c|c|}
\hline \multicolumn{1}{|c|}{ Reservoir } & $\begin{array}{c}\text { Geoaccu- } \\
\text { mulation } \\
\text { index } \boldsymbol{I}_{\text {geo }}\end{array}$ & $\begin{array}{c}\text { Contam- } \\
\text { ination } \\
\text { factor } \boldsymbol{C}_{f}\end{array}$ & PIG $^{*}$ \\
\hline Rybnik & 0.36 & 3.40 & $\mathrm{II}$ \\
\hline Rzeszów & 0.05 & 1.67 & $\mathrm{I}$ \\
\hline Bagna Rzeszowskie & 0.32 & 3.16 & $\mathrm{II}$ \\
\hline Głuchów & -0.40 & 0.59 & $\mathrm{I}$ \\
\hline Narożnik & -0.59 & 0.39 & $\mathrm{I}$ \\
\hline Brzóza Królewska & -0.26 & 0.82 & $\mathrm{I}$ \\
\hline Brzóza Stadnicka & -0.19 & 0.97 & $\mathrm{I}$ \\
\hline Ożanna & -0.06 & 1.30 & $\mathrm{I}$ \\
\hline
\end{tabular}

${ }^{*}$ Classes: $I$ - unpolluted sediments, II - sediments moderately polluted, III - sediments of medium pollution, IV-sediments heavily polluted. 
The $C_{f}$ value for the above mentioned sediments was above 3 , which corresponds to their heavy pollution with mercury. Moderate mercury pollution $\left(1 \leq C_{f}<3\right)$ was recorded in sediments of the Ożanna and Rzeszów reservoirs. A low coefficient of contamination $\left(C_{f}<1\right)$ was observed in the sediments of the reservoirs in Głuchów, Narożniki, Brzóza Królewska and Brzóza Stadnicka (Tab. 3). According to the PIG (Polish Geological Institute) classification, the sediment samples were classified into class I unpolluted sediments and class II moderately polluted sediments (Bojakowska 2001).

Elevated concentrations of mercury in bottom sediments of the reservoirs in Rybnik and Bagna Rzeszeszowskie are related to their short distance to large urban agglomerations and industrial plants (the Rybnik Reservoir). The bottom sediments from the Rybnik Reservoir are generally an effect of intensive anthropopression of the area where reservoirs are located. Treated industrial sewage, emitted by the Rybnik power plant, municipal sewage, rain wastewaters, sewage from the water treatment plant, cooling tower blowdowns, and dry precipitation all represent the main kinds of water contamination in the reservoir and in the Ruda River (Koniarz et al. 2014). The Brzóza Stadnicka Reservoir, which acts as the initial reservoir, affects the lower mercury contamination of the bottom sediments in the downstream reservoir of Brzóza Królewska.

\section{CONCLUSIONS}

1. To summarize, the concentration of mercury in bottom sediments follows the order of: Rybnik > Bagna Rzeszowskie > Rzeszów > Ożanna > Brzóza Stadnicka > Brzóza Królewska > Głuchów > Narożniki.

2. The research results show that the 13 samples indicated are above the Polish $\mathrm{Hg}$ background. Only 9 samples are below the background. Generally, the sediments belonged to class I and II (unpolluted and moderately polluted sediments).

3. Low mercury concentration in the studied sediments is generally related to a lack of anthropogenic sources of this metal.
4. A positive significant correlation between the concentration of organic matter and the mercury concentration confirms the considerable share of organic matter in the binding of mercury. This means, that organic matter is likely to be the most important factor affecting the concentration and distribution of mercury in the studied sediments.

The work was financed by grant No. NN305 295037 provided by the National Science Centre, and from the subsidy for science DS-3322/KIWiG and DS-3101/KChRiS granted by the Polish Ministry of Science and Higher Education.

\section{REFERENCES}

Baran A. \& Tarnawski M., 2013. Phytotoxkit/Phytotestkit and Microtox as tools for toxicity assessment of sediments. Ecotoxicological and Environmental Safety, 98, 19-27.

Baran A., Tarnawski M. \& Jasiewicz Cz., 2011. Assessment of the content and solubility of heavy metals in bottom sediments of Chancza reservoir. Ecological Chemistry and Engineering. A., 18, 7, 941-950.

Bojakowska I., Gliwacz T. \& Małecka K., 2006. Wyniki geochemicznych badań osadów wodnych Polski w latach 2003-2005. Biblioteka Monitoringu Środowiska, Inspekcja Ochrony Środowiska, Warszawa.

Bojakowska I., 2001. Kryteria oceny zanieczyszczeń osadów wodnych. Przegląd Geologiczny, 49, 3, 213-219.

Boszke L., Głosińska G. \& Siepak J., 2002. Some aspect of speciation of mercury in a water environment. Polish Journal of Environmental Studies, 11, 4, 285-298.

Boszke L., Kowalski A, Głosińska G., Szarek R. \& Siepak J., 2003. Environmental factors affecting speciation of Mercury in the bottom sediments; an overview. Polish Journal of Environmental Studies, 12, 1, 5-13.

Capri A. \& Lindberg S.E., 1997. Sunlight-Mediated Emission of Elemental Mercury from Soil Amended with Municipal Sewage Sludge. Environmental Science Technology, 31, 2085-2091.

Farkas A., Erratico C. \& Vigano L., 2007. Assessment of the environmental significance of heavy metal pollution in surficial sediments of the River Po. Chemosphere, 68, 761-768.

Ferguson J.E., 1990. The heavy elements: chemistry environmental impact and healthy effects. Pergamon Press, Oxford.

Håkanson L., 1980. An ecological risk index for aquatic pollution control. A sedimentological approach. Water Research, 14, 975-1001.

Hintelman H. \& Wilken R-D., 1995. Levels of total mercury and methylmercury compounds in sediments of the polluted Elbe River: influence of seasonally and spatially varying environmental factors. Science of Total Environment, 166, 1-3, 1-10. 
Kabata-Pendias A. \& Pendias H., 1999. Biogeochemia pierwiastków śladowych. PWN, Warszawa.

Koniarz T., Tarnawski M. \& Baran A., 2014. Content of lead in bottom sediments of the water reservoir located in urban area. Logistic, 4, 4445-4453.

Lis J. \& Pasieczna A., 1995. Atlas geochemiczny Polski: 1:2500000 = Geochemical Atlas of Poland: 1:2500000. Państwowy Instytut Geologiczny, Warszawa.
Müller G., 1981. Die Schwermetallbelastung der Sedimenten des Neckars und seiner Nebenflüsse. Chemiker-Zeitung, 6, 157-168.

Tarnawski M., Florencka N. \& Baran A., 2013. Mercury in the Bottom Sediments of the Water Retention Reservoirs. E3S Web of Conferences, 1, 06005.

Milestone productivity tools, [on-line:] http://www.milestonesci.com (access: November 2014). 